\title{
Correction to: CPAP Compliance in Obstructive Sleep Apnea
}

\author{
Manvir Bhatia ${ }^{1} \mathbb{D} \cdot$ Yogendra Singh $^{2}$
}

Published online: 14 October 2019

(c) Springer Nature Singapore Pte Ltd. 2019

\section{Correction to: Sleep and Vigilance}

https://doi.org/10.1007/s41782-019-00070-8

The article "CPAP Compliance in Obstructive Sleep Apnea" written by Manvir Bhatia, was originally published electronically on the publisher's internet portal (currently SpringerLink) on August 10, 2019 with open access. With the author(s) decision to step back from Open Choice, the copyright of the article changed to $\odot$ Springer Nature Singapore Pte Ltd. 2019 and the article is forthwith distributed under the terms of copyright.

The original article has been corrected.

The original article can be found online at https://doi.org/10.1007/ s41782-019-00070-8.

Manvir Bhatia

drmbhatia@gmail.com

1 Neurology Sleep Centre, New Delhi, India

2 Department of Pulmonary Medicine and Sleep Disorders, All India Institute of Medical Sciences, New Delhi, India 